Transnational Business Governance Interactions Project

Working Paper No. 28

October 2018

\title{
Can Non-State Regulatory Authority Improve Domestic Forest Sustainability? Assessing Interactive Pathways of Influence in Cameroon
}

\section{Sophia Carodenuto}

University of Victoria

Benjamin Cashore

Yale University

This paper is available free of charge from http://www.tgiforum.org

TBGI Project Working Paper No. 28

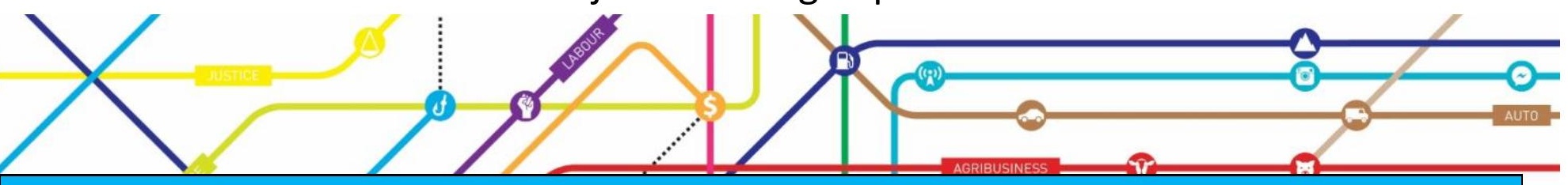

The TBGI Project: Transnational initiatives to regulate business activities interact increasingly with each other and with official regulation, generating complex governance ensembles. Heterogeneous actors and institutions interact at multiple levels and in various ways, from mimicry and cooperation to competition and conflict. The TBGI Project investigates the forms, drivers, mechanisms, dynamics, outputs and impacts of transnational business governance interactions (TBGI) from diverse theoretical and methodological perspectives. It is led by Stepan Wood, Professor and Canada Research Chair in Law, Society and Sustainability at the Peter A. Allard School of Law, University of British Columbia.

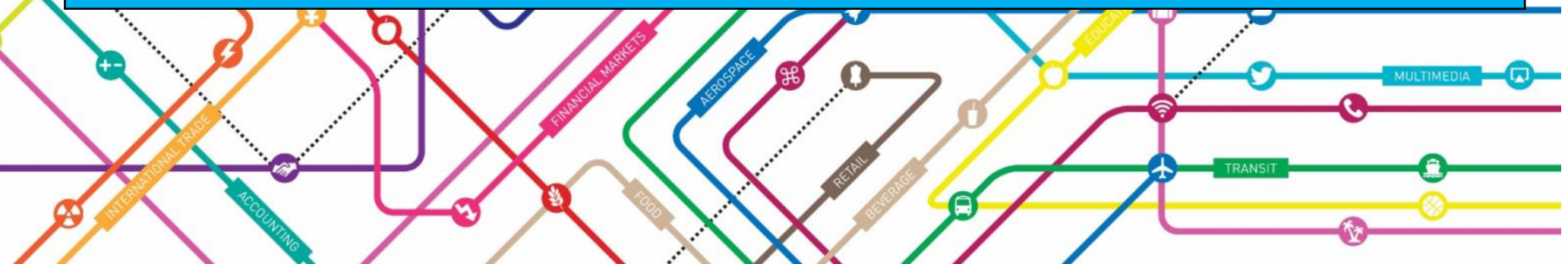




\title{
Can Non-State Regulatory Authority Improve Domestic Forest Sustainability? Assessing Interactive Pathways of Influence in Cameroon
}

\author{
Sophia Carodenuto and Benjamin Cashore ${ }^{1}$
}

\begin{abstract}
Transnational business governance can involve the use of non-state mechanisms to target the behavior of firms within domestic settings. Drawing on the implementation pillar of the TGBI framework, this chapter focuses attention on the interaction between state and non-state regulatory authority from two leading cases of TBG in tropical forest management: climate mitigation through avoided deforestation (REDD+) and timber legality verification through international trade agreements (FLEGT/VPA). A dominant justification among global elites for both interventions is that empowering marginalized domestic groups through technology transfer and capacity building will lead to more durable policy solutions on the ground. Drawing on empirical evidence in Cameroon, we argue that contrary to these justifications, REDD+ and FLEGT/VPA at best may not succeed in addressing the underlying power structures, and at worst have unintended and possibly adverse consequences on marginalized peoples. This is largely because the policy mechanisms were generally conceived prior to, and independent of, their application in particular domestic settings, often making them ill-suited to the unique circumstances of the forest sectors in which they operate. We conclude by providing insights as to how these policies may be designed to improve their durability.
\end{abstract}

\section{Keywords}

Reducing Emissions from Deforestation and forest Degradation, sustainable management of forests, conservation and enhancement of forest carbon stocks in developing countries (REDD+).

\section{Introduction}

Ever since international efforts failed to achieve a legally binding agreement on forests at the 1992 United Nations Conference on Environment and Development, a plethora of targeted interventions have emerged to address key challenges surrounding sustainable forest management. Two of the most important problem definitions with significant repercussions in tropical forest countries such as Cameroon include (1) tropical deforestation and associated climate impacts; and (2) the proposition that international timber trade, especially owing to demand in consumer countries, contributes to illegal forest activities in (sub) tropical forests. These two problem definitions have led to the development of two policy approaches.

1 Sophia Carodenuto, Assistant Professor, Department of Geography, University of Victoria. carodenuto@uvic.ca. Benjamin Cashore, Professor, Environmental Governance \& Political Science; Director of the Governance, Environment, and Markets Initiative at Yale (GEM) and Director, Program on Forest Policy and Governance, Yale University. benjamin.cashore@yale.edu. A revised version of this paper is forthcoming in Stepan Wood et al., eds. Transnational Business Governance Interactions: Empowering Marginalized Actors and Enhancing Regulatory Quality. Cheltenham, UK: Edward Elgar. 
To address climate change, negotiators working under the auspices of the United Nations Framework Convention on Climate Change (UNFCCC) have proposed the mitigation-focused policy approach "Reducing Emissions from Deforestation and forest Degradation, sustainable management of forests, conservation and enhancement of forest carbon stocks in developing countries" (REDD+). The main incentives for REDD+ are financial: developing countries are given compensation for verified forest-related carbon emissions reductions. In parallel, the European Union's Forest Law Enforcement, Governance and Trade (FLEGT) Action Plan applies demand- and supply-side trade measures to address illegal forest activities. Responding to customer and consumer demand, the European Union Timber Regulation (EUTR) creates incentives for legal compliance by prohibiting the importation of illegally harvested timber and wood products By weeding out illegal supply, this prohibition is expected to secure markets for legally produced timber. The EU also enters into Voluntary Partnership Agreements (VPAs) with timber-exporting countries as a way to formalize legality requirements and guarantee access to the European market. As a result, much attention is focused, through VPAs, on helping develop national timber tracing and legality assurance systems.

Architects of both REDD+ and FLEGT embrace increasing complexity (Rayner et al. 2010) by turning to non-state actors and domestic firms to foster behavior changes (Bernstein \& Cashore 2012). Hence, they are part of the transnational business governance (TBG) phenomenon that Eberlein et al $(2014$, p. 3) define as "systematic efforts to regulate business conduct that involve a significant degree of non-state authority in the performance of regulatory functions across national borders." REDD+ and FLEGT involve the exercise of both state and non-state authority, including multi-lateral funding programs, international non-governmental organizations, aid organizations, and multi-national forestry and agribusiness firms, to name a few (McDermott et al. 2012).

Given the increasing use of TBG to address what used to be the subject of international negotiations and treaties, we turn our attention to understanding the effects of these global efforts on influencing the complex governance challenges at the domestic level. We shed light on this broad quest by posing the following question: "Do the domestic-level governance interactions brought about by global TBG initiatives such as REDD+ and FLEGT lead to durable sustainability impacts on the ground?"

To address this question we take a closer look at the precise way in which these policy instruments are influencing Cameroon's domestic forest challenges. Cameroon is a relevant case because of the important ecological, economic and social contributions of its forests (Lescuyer et al. 2016), and the attention that global elites have placed on REDD+ and legality verification to improve practices on the ground. Over $40 \%$ of Cameroon's land is covered by dense humid forest, forming an important part of the Congo Basin tropical forest biome. The country exports timber to the EU and is also home to large areas of tropical forest viewed as critical for potential REDD+ projects (Bourges et al. 2014; Wasseige et al. 2012). National policy makers have identified deforestation and illegal forest activities as critical problems that increasingly place the country's forest at risk. Roughly a decade ago, Cameroon became engaged in REDD+ by submitting an initial funding application to the Forest Carbon Partnership Facility (FCPF) and, around that same time, entered preliminary VPA negotiations with the EU. Cameroon was one of the pioneer FLEGT countries, possibly because early studies on illegal logging suggested that the majority of illegally harvested tropical timber found on EU markets originated in or passed through Cameroon (Hirschberger 2008). Cameroon is the transit country for timber from neighboring countries such as Central African Republic and Republic of Congo, and the timber's country of origin is often indistinguishable due to weak supply chain tracking (Lawson \& MacFaul 2010, p. 113).

\section{Analytical framework}

Consistent with social science research on policy cycles or stages in general (Lasswell, 1956 and Howlett, 1995) and the TGBI framework in particular, we place attention on what is commonly 
referred to as the implementation phase of the policy cycle: where attention turns to the types of specific calibrations, mechanisms and policy settings that are often determined following the formal adoption of policy goals, objectives, and instruments (Hall 1993). To unpack these complex processes that unfold over time, we draw on Bernstein and Cashore's "pathways of influence" framework to disentangle distinct causal mechanisms through which global policy measures influence the domestic level (Bernstein \& Cashore 2012).

We draw on a meta-analysis of five empirical case studies conducted during the course of multiple research stays in Cameroon from 2011 until 2015. Two case studies focus on different elements of FLEGT/VPA implementation (Carodenuto \& Cerutti 2014; Carodenuto \& RamcilovicSuominen 2014), two concentrate on REDD+ implementation (Carodenuto et al. 2015; Carodenuto \& Kalame 2015), and the fifth links the analysis of the two policies (Carodenuto 2016). The data for the first two case studies are twenty-four semi-structured interviews with Cameroon's private forestry sector. The purpose of the interviews was to better understand and empirically assess the benefits of and barriers to FLEGT/VPA implementation. The first case on REDD+ examined the analytical process of developing Cameroon's REDD+ strategy by proposing and testing a methodology for assessing the causes of deforestation and forest degradation to be addressed by the future national REDD+ strategy. The other case on REDD+ studied Cameroon's social safeguards approach through a legal review combined with participant observation of the national process of developing Free, Prior and Informed Consent (FPIC) guidelines for REDD+. The final case study included ten semi-structured interviews with civil society representatives from environmental and social organizations based in Cameroon's Southwest Region. This case study analyzed the potential of the information transparency instruments proposed by REDD+ and FLEGT to achieve improved accountability in Cameroon's forest governance.

\section{Pathways of influence}

Bernstein and Cashore's work on pathways of influence $(2000,2012)$ was designed to conceptualize and assess the role of non-domestic factors in shaping domestic policy-making processes. This approach is highly relevant because the FLEGT/VPA and REDD+ in Cameroon epitomize internationalization trends in environmental policy making characterized by a shift from government regulations dominating forest decision-making to a more complex governance environment marked by interactions introduced by multiple governance mechanisms, international institutions and transnational actors (Buttoud 2011; Rayner et al. 2010). The pathways of influence framework (Figure 1) helps to reveal the underlying assumptions and expectations about a policy's trajectory, potentially explaining why support for an intervention might occur (Cashore 2015). We argue that unpacking the dominant paradigm or discourse underpinning a given policy intervention, i.e. the assumed causal logic, is helpful in better understanding policy implementation. 
Figure 1: TBG pathways of influence

\begin{tabular}{|c|c|c|}
\hline \multirow{5}{*}{$\begin{array}{l}\text { Global forest } \\
\text { governance } \\
\text { agenda }\end{array}$} & Pathways of influence & Causal logic \\
\hline & $\begin{array}{l}\text { Rules- Formal legal } \\
\text { obligations, treaties }\end{array}$ & $\begin{array}{l}\text { Degree of } \\
\text { enforcement/penalties } \\
\text { leading to compliance }\end{array}$ \\
\hline & $\begin{array}{l}\text { Markets- Economic } \\
\text { incentives or } \\
\text { disincentives }\end{array}$ & $\begin{array}{l}\text { Degree of market } \\
\text { access, perception of } \\
\text { incentives }\end{array}$ \\
\hline & $\begin{array}{l}\text { Norms- ideas and } \\
\text { values, such as } \\
\text { biodiversity or rights }\end{array}$ & $\begin{array}{l}\text { Strength of the norm, } \\
\text { ability to influence } \\
\text { behavior }\end{array}$ \\
\hline & $\begin{array}{l}\text { Direct access- } \\
\text { empowerment of } \\
\text { domestic actors }\end{array}$ & $\begin{array}{l}\text { Degree to which } \\
\text { marginalized groups are } \\
\text { empowered }\end{array}$ \\
\hline
\end{tabular}

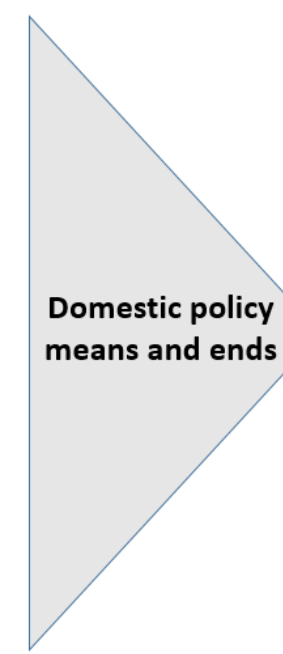

Source:

Adapted from Bernstein and Cashore (2000, 2012)

Each pathway turns attention to different causal explanations as to why TBG processes have influence within a given domestic setting. The rules pathway turns attention to formal legal obligations, such as international treaties translated into laws ratified at the national level. The causal logic relevant here reflects a 'command and control' approach, where the TBG regime's traction can be judged by the degree to which compliance to the rule is mandatory, for example through enforcement or penalties. Ultimately, this pathway is considered influential not simply when rules exist, but when these rules are adhered to. The markets pathway focuses on "economic incentives for firms, managers and individuals, to behave in ways that improve environmental stewardship and foster social values" (Panwar et al. 2016, p. 45). This pathway's causal logic is based on economic theories that portray individuals and organizations as rational and narrowly self-interested agents whose ultimate aim is to maximize financial gain, i.e. homo economicus. The norms pathway refers to the influence of broadly accepted principles such as respect for the sovereignty of nation states and in the environmental sphere - the importance of preserving biodiversity and respecting human rights of affected groups. Finally, the direct access pathway refers to the use of finance and technology transfer to empower public and private domestic actors. Influence along this pathway can occur through direct funding, education, and capacity building, including through attempts at co-governance via partnerships between domestic and international actors. Bernstein \& Cashore (2012) explain that the logic underlying this pathway is the degree to which marginalized groups are empowered.

\section{Policy implementation: a nuanced look at ends, means, and settings}

Consistent with the TGBI framework, we expand the more targeted emphasis that usually accompanies a discussion of 'implementation' to review [1] the overarching goals that guide policy in a particular field, [2] the techniques or policy instruments used to attain those goals, and [3] the precise settings of these instruments" (Hall 1993, p. 278). Disaggregating FLEGT/VPA and REDD+ can help identify which logics of influence emerge as dominant and, thereby, where policy implementation, and hence influence, is hampered (Cashore \& Howlett 2007). ${ }^{2}$ This analytical

\footnotetext{
${ }^{2}$ Cashore and Howlett expand Hall's typology to identify six, not three ways to classify policy choices: endsfocused goals, objectives and settings; and means-focused instrument logics, mechanisms and calibrations. We use these distinctions to guide our broad analysis, rather than probe deeply into each one, which is beyond the
} 
perspective highlights an important set of mechanisms often overlooked in the TBG literature: the tools and techniques of regulatory governance.

The empirical research conducted for this chapter identified two main types of policy instruments currently employed for REDD+ and FLEGT/VPA implementation in Cameroon: 1) highly technical information transparency instruments related to timber tracking and legality verification, e.g. the timber legality assurance system (TLAS) ${ }^{3}$; and 2) procedural tools that aim to broaden the number and type of actors engaged in REDD+ and FLEGT/VPA, e.g. multi-stakeholder consultations and FPIC as a standard for engaging marginalized actors.

\section{Analysis: FLEGT/VPA and REDD+ Pathways of Influence in Cameroon Unpacking the FLEGT/VPA}

The EU FLEGT Action Plan's main policy goal is to reduce illegal logging and related trade. However, the Action Plan also has explicit aims to foster forest sector growth and economic development and to improve forest governance (EC 2003). These overarching goals are taken up by VPA countries, with Cameroon's VPA emphasizing socioeconomic development as a main desired outcome of the VPA process. Thus, Cameroon's VPA intends not only to satisfy the timber legality requirements of the EUTR, but also to foster sustainable forest sector growth and "encourage economic opportunities for resident local communities and local enterprise" (ROC \& EU 2010, p. 9). ${ }^{4}$

The timber legality assurance system (TLAS) is the dominant policy instrument for implementing FLEGT/VPA in Cameroon. This system aims to verify the legality of all pertinent wood products circulating in Cameroon, including those sold on the domestic market, as this is thought to reduce the risk of leakage of non-compliant timber into export markets. In many VPA countries, including Cameroon, the amount of timber traded domestically is roughly equal in volume to that exported (Wit et al., 2010; Cerutti and Lescuyer, 2011; Hansen et al., 2012). Once operational, the TLAS will allow EU-exporting forest enterprises to receive FLEGT licenses, thereby granting them automatic access to EU markets. Cameroon's TLAS has been designed to give the Government the final say in whether a batch of timber receives a FLEGT legality certificate or not, as a governmentbased 'licensing authority' is designated by Cameroon to issue and validate FLEGT licenses for each timber shipment (ROC \& EU 2010, p. 6; Fripp et al. 2013).

In the case of Cameroon, the precise settings of the TLAS instrument have focused on formal law, or written rules, i.e. state legislation that prescribes the official documentation a timber operator must obtain in order to comply with FLEGT legality. Because the TLAS as currently proposed applies to all timber circulating in Cameroon, VPA implementation risks harming local timber operators because the domestic market is based on informal rules and procedures, falling entirely outside formal law

\footnotetext{
scope of a single chapter. Rather, we simply make the point that distinguishing different types of policy choices can help better understand the pathways through which TBG instruments may have shaped, or failed to shape, domestic policy.

${ }^{3}$ As explained in detail by Gupta and Mason (2016), REDD+ Measurement, Reporting and Verification (MRV) national forest monitoring systems that are required for REDD+ countries to access REDD+ payments - have characteristics similar to the TLAS in terms of being an expert-led, problem-solving approach mired by technical complexity. A review of the design and implementation of Cameroon's proposed MRV system is not included in this chapter.

${ }^{4}$ Article 2 of the Agreement outlines the VPA's objectives, which states the Parties agree to: a) "promote trade in timber and derived products; b) establish a basis for dialogue and cooperation; c) to promote the development of the forest industries in Cameroon and to thereby improve the competitiveness of the sector; $d$ ) create and encourage economic opportunities for resident local communities and local enterprises; e) to strengthen the capacities of actors in Cameroon by encouraging the creation of a favorable climate for investment in the sustainable management of forests" (ROC \& EU 2010, p. 9 emphasis added).
} 
(Cerutti \& Lescuyer 2011). Small-scale loggers operating informally were not directly represented as a stakeholder during the VPA negotiations when such fundamental elements of the TLAS were agreed (Woodshow et al. 2016).

\section{Unpacking REDD+}

Similar to the FLEGT/VPA, REDD+ in Cameroon encompasses a number of overarching (global) goals that have been translated into specific objectives at the national level. To mitigate climate change, REDD+ aims to transfer funds to equitably compensate developing countries for their sustainability efforts. Similar to many REDD+ countries, Cameroon has integrated social and environmental safeguards as a mechanism not only to avoid harm, but also to improve the status quo, specifically biodiversity and respect for the human rights of marginalized forest communities (Visseren-Hamakers et al. 2012). Similar to the VPA, REDD+ in Cameroon aims to improve forest governance and increase information transparency, thereby allowing a broader range of (marginalized) stakeholders to participate in decision-making processes surrounding forests.

The dominant policy instruments currently perceptible in Cameroon in connection with REDD+ are procedural instruments such as awareness raising, information dissemination, and multistakeholder consultation. This is largely explained by the fact that Cameroon remains in the so-called "readiness" phase of REDD+, where institutions and stakeholders are preparing REDD+ strategies to be implemented in the future. At the time of writing, Cameroon has not yet succeeded in transferring international climate finance to land-based investments to reduce forest-related emissions as a result of REDD+. Nonetheless, REDD+ has raised significant expectations, especially amongst highly vocal civil society groups advocating for interests and rights of local communities in the national REDD+ policy process (Somorin et al. 2014, p. 91). Social safeguards advocacy is driven not only by the campaign for protecting the rights of marginalized indigenous communities, but also by the longstanding struggle to demand political reform towards more democratic institutions (AssembeMvondo et al. 2014). An exemplary policy instrument in this case (and analyzed more in detail in this chapter) is the development of national guidelines for Free, Prior and Informed Consent (FPIC) for REDD+ activities that take place where indigenous and other forest communities live. The aim of FPIC in the context of REDD+ is to advocate for the right to self-determination, specifically with regard to the rights of indigenous people to determine whether, and what type of, development occurs on their traditionally held land.

In contrast to the TLAS, the precise settings of the FPIC guidelines for REDD+ are based on informal norms, defining consent as "the collective decision made by rights-holders and reached through the customary decision-making processes of the affected peoples or communities" (MINEPDED, 2014). These FPIC guidelines are not legally binding, as they have yet to be converted into specific regulations that guide practices on the ground and render them enforceable (Carodenuto \& Kalame 2015). Further, the state agency tasked with enforcing adherence to such guidelines, the Ministry of Environmental Protection and Sustainable Development (MINEPDED), does not currently possess the manpower or resources required to effectively enforce these FPIC guidelines (ibid.).

\section{Direct Access: the dominant pathway}

Figure 2 summarizes the potential pathways of influence by which the TBG processes of REDD+ and FLEGT/VPA might affect domestic policy settings in Cameroon, and the evidence for each pathway. Although REDD+ and FLEGT/VPA may have originally employed the rules, markets, and norms pathways, their translation into Cameroon's domestic policy implementation is dominated by the direct access pathway, especially with regard to the policy instruments through which both TBG processes are being implemented. Again, this may be explained by the fact that both TBG processes remain in the preparation phase, dominated by significant financial and technical support, and the policy mechanisms exerting influence via markets or rules have not yet materialized. The causal logic 
of the direct access pathway - the degree to which marginalized groups are empowered - explains the support for information transparency systems, multi-stakeholder deliberations, and local training and capacity building to facilitate broad stakeholder participation.

Figure 2: Pathways of influence for FLEGT/VPA and REDD+ in Cameroon*

\begin{tabular}{|c|c|c|}
\hline Pathway & Potential influence & Evidence of influence \\
\hline \multirow[t]{2}{*}{ Markets } & $\begin{array}{l}\text { FLEGT/VPA: "green lane" access to } \\
\text { EU markets for timber with FLEGT } \\
\text { legality certificate }\end{array}$ & $\begin{array}{l}\text { Weak: FLEGT legality certificates } \\
\text { have not yet been produced as } \\
\text { proposed through the TLAS }\end{array}$ \\
\hline & $\begin{array}{l}\text { REDD+: access to international } \\
\text { climate finance markets and } \\
\text { performance-based payments }\end{array}$ & $\begin{array}{l}\text { Weak: Performance-based payment } \\
\text { have not yet materialized and no } \\
\text { REDD+ carbon-based transactions }\end{array}$ \\
\hline \multirow[t]{2}{*}{ Rules } & $\begin{array}{l}\text { FLEGT/VPA: VPA ratification into } \\
\text { national law renders the FLEGT } \\
\text { legality criteria legally enforceable }\end{array}$ & $\begin{array}{l}\text { Weak: Law enforcement and rule of } \\
\text { law remains weak in forest sector, } \\
\text { difficulty in verifying the compliance } \\
\text { underlying legal "papers" }\end{array}$ \\
\hline & $\begin{array}{l}\text { REDD+: FPIC becomes legally } \\
\text { enforceable through passing of } \\
\text { regulatory decree }\end{array}$ & $\begin{array}{l}\text { Weak: FPIC guidelines remain legally } \\
\text { unenforceable given lack of regulator } \\
\text { decree }\end{array}$ \\
\hline \multirow[t]{2}{*}{ Norms } & $\begin{array}{l}\text { FLEGT/VPA: Non-state actors in } \\
\text { Cameroon bring about change as a } \\
\text { result of their governance, } \\
\text { transparency and accountability } \\
\text { agenda }\end{array}$ & $\begin{array}{l}\text { Moderate: Financial and technical } \\
\text { support provided to numerous non- } \\
\text { state actors, but the change in } \\
\text { business as usual remains difficult to } \\
\text { quantify }\end{array}$ \\
\hline & $\begin{array}{l}\text { REDD+: Safeguards advocacy brings } \\
\text { about improved recognition of the } \\
\text { rights of marginalized indigenous } \\
\text { people and forest communities }\end{array}$ & $\begin{array}{l}\text { Weak: The impact of national FPIC } \\
\text { guidelines remains mitigated without } \\
\text { the government officially recognizing } \\
\text { certain groups that have self- } \\
\text { identified as indigenous }\end{array}$ \\
\hline \multirow[t]{2}{*}{ Direct Access } & $\begin{array}{l}\text { FLEGT/VPA: Marginalized actors are } \\
\text { empowered to demand the forestry } \\
\text { sector in Cameroon provides } \\
\text { equitable and sustainable } \\
\text { development }\end{array}$ & $\begin{array}{l}\text { Substantial: Significant transfer of } \\
\text { technology and finance, which is } \\
\text { helping civil society and other actors } \\
\text { to become more vocal }\end{array}$ \\
\hline & $\begin{array}{l}\text { REDD+: Marginalized actor are } \\
\text { empowered to ensure REDD+ } \\
\text { supports equitable and sustainable } \\
\text { rural development }\end{array}$ & $\begin{array}{l}\text { Substantial: Significant transfer of } \\
\text { technology and finance, which is } \\
\text { helping civil society and other actors } \\
\text { to become more vocal }\end{array}$ \\
\hline
\end{tabular}

*Note: The elements listed in this table are not exhaustive, as the examples used do not aim to demonstrate all goals and instruments of the VPA and REDD+, but rather to summarize the key findings of this chapter's metaanalysis. 


\section{Implications for FLEGT/VPA}

Delivering FLEGT legality certificates appears to be the most pressing short-term goal for VPA implementation in Cameroon. This requires an operational TLAS. However, Carodenuto \& RamcilovicSuominen (2014) find that understanding the complexity of the current TLAS requires specialized knowledge held only by select experts, which works to limit the participation and influence of nonexpert officials within the forest administration and the forestry sector. The impact of technical knowledge in excluding, rather than empowering, stakeholders is a common theme within contemporary scholarship on environmental governance. Gupta \& Mason (2016) suggest that 'governance by disclosure' for environmental sustainability is increasingly based on a 'technocratic' rationale. This, in turn, involves implementing information transparency instruments that develop elaborate systems of professional auditing and legality certification that only those with time and expertise can fully comprehend. Hence, and somewhat ironically, the transformative potential of transparency is often reduced as the resulting 'technocracy' can counteract originally intended democratization objectives of using disclosure to enhance accountability, participation and citizens' right to know (ibid.). This means that policy instruments must be designed and specified carefully in ways that develop technical procedures that empower, rather than detract from, inclusive governance. This may be achieved by involving non-experts in the design and implementation of these technically complex instruments.

The TLAS' highly technical approach has led to the involvement of numerous financial and technical partners that provide significant training and capacity building to support TLAS operationalization. Thus, the direct access pathway emerges as dominant, which implies that the causal logic for successful FLEGT/VPA implementation is the empowerment of marginalized actors. While it is too early to draw conclusions on the ability of the VPA to have this type of positive impact, Carodenuto \& Cerutti (2014) indicate that the EU market access benefits resulting from VPA/TLAS will not diffuse to the majority of Cameroon's private forestry operators, who operate informally and serve local timber markets. Rather, multinational forestry companies that enjoy niche export markets through pre-existing Forest Stewardship Council (FSC) certification appear positioned to reap the most benefits. In fact, many timber operators believe that the informal sector will be eliminated as a result of VPA implementation while multinational forestry companies operating at an industrial scale expect VPA implementation to increase their market share (Carodenuto \& Cerutti 2014).

\section{Implications for REDD+}

Similar to other transnational forest governance processes, REDD+ influences domestic policy largely through capacity building, characterized by the provision of financial resources to assist existing civil society organizations or to help create new organizations (Bernstein \& Cashore 2012, p. 594). Procedural instruments dominate, such as the multi-stakeholder consultation process conducted to develop the FPIC guidelines, or the consultation process currently underway to develop the national REDD+ strategy. These reflect the widely accepted paradigm shift in forest policy making (and implementation) from top-down forest management by professionals to more inclusive forest governance approaches involving a broad range of stakeholders. The input legitimacy that arises from effective participatory processes has long been considered essential for maintaining societal support in liberal democracies and is considered an important contributing factor to successful policy implementation (Buttoud 1999). What remains unclear, however, is the extent to which capacity building and stakeholder learning through consultative fora can effect the kind of transformational change required to effectively allow for REDD+ to stimulate socially equitable rural development.

As with the FLEGT/VPA, much of the domestic influence of REDD+ has occurred through the direct access pathway. Specifically, decisions to implement REDD+ focused on provision of financial resources for capacity building. The instrument logic was that this would empower marginalized stakeholders and, as a result, enhance domestic good forest governance by improving the legitimacy of the system. Although influence through the provision of finance "can help shift the balance of 
power in domestic policy processes," broader contextual factors such as "democracy, openness and accountability are prerequisites for the successful use of this strategy" (Bernstein \& Cashore 2012, p. 594). The REDD+ process in Cameroon produced FPIC guidelines that ultimately aim to enshrine adequate mechanisms for the meaningful participation of indigenous and other communities whose customarily owned land and forests are affected by REDD+. However, these guidelines are not legally enforceable and stem from a Ministry that does not have the resources nor the on-the-ground presence required to support interpretation and application of the guidelines (Carodenuto \& Kalame 2015). Therefore, the REDD+ process has to date emphasized procedural efforts with less attention to policy specification such as the passing of legally binding regulations, budget allocations, or policy adjustments to foster compliance with or mainstreaming of REDD+, including safeguards standards. This seems problematic for REDD+'s long-term influence, since provision of finance may facilitate initial uptake domestically, but is often less effective in influencing policy and legal frameworks (Bernstein \& Cashore 2012).

\section{Interaction: State and non-state regulatory authority}

The direct access pathway's causal logic is that through capacity building and additional resources, disempowered communities and other stakeholders are more likely to influence the domestic policy process, shaping outcomes and (potentially) impacts. The hypothesis is that policy solutions that travel this pathway are more durable as they influence the political economy of the given national context. For example, building non-state actors' capacity could better enable civil society to access, digest, and use information for the purpose of independent monitoring of forestry operations, which is a key component of VPA implementation. ${ }^{5}$

The direct access pathway is often travelled by those advancing 'new governance' approaches that take a richer set of actors into account for operationalizing policy on the ground (Melish \& Meidinger 2012). In this context, the interaction between state and non-state actors aims to empower marginalized actors, specifically in terms of their ability to exert regulatory governance. However, consistent with the literature (Bartley 2014; Cashore \& Stone 2014) the findings generally indicate that neither REDD+ nor timber legality have been designed in a way to accomplish this type of empowering process. Instead, policies reinforce national sovereignty and the substantive duty of states to enforce compliance. For example, the TLAS is designed in such a way that the government and its line authorities have the sole capacity to input data into the TLAS, and ultimately the government has full discretion over what is considered legal timber or not (Carodenuto \& Cerutti 2014; Carodenuto \& Ramcilovic-Suominen 2014). This corroborates other scholarship that finds that "legality verification' efforts that seek to identify and label legal products along global supply chains are designed to champion and reinforce existing government policies" (Cashore et al. 2016) rather than create new and potentially more empowering policy reforms. With regard to REDD+, Carodenuto \& Kalame (2015) review how the FPIC guidelines - in line with international laws that recognize FPIC as a legal norm imposing clear affirmative duties on States - place ultimate responsibility on the State to ensure that REDD+ project implementers obtain FPIC. Further, these guidelines do not properly address the issue of the absence of formal recognition of customary land tenure rights.

Given that our findings suggest that both REDD+ and FLEGT/VPA aim to reinforce the regulatory authority and capacity of the state, the perceived legitimacy of the state may therefore have implications for policy implementation. Private sector operators across the board (from both industry and the informal sector) cite government corruption as the most important barrier to VPA implementation (Carodenuto \& Ramcilovic-Suominen 2014)This is corroborated by other studies, highlighting that trust and accountability are lacking, especially in the forest sector (Cerutti et al. 2013). The VPA seeks influence by building trust and accountability through building the capacity of

\footnotetext{
${ }^{5}$ See VPA Article 16 : Participation of the stakeholders in the implementation of the Agreement.
} 
the national forest control authorities and introducing timber tracing and legality verification through the TLAS.

\section{Outlook: linking pathways of influence and TBGI}

The pathways of influence framework helps to better understand the explanatory logics underpinning TBG processes and the resulting interaction between state and non-state actors in domestic policy settings. The case of Cameroon suggests that REDD+ and FLEGT rely largely on the direct access pathway, implying that they build on the assumption that empowering marginalized groups will foster more durable policy solutions. However, the current structure and legal framework of the forest sector excludes smallholder artisanal loggers from reaping the potential benefits of VPA implementation as they are not able to export to the EU. Further, the current technical complexity of the FLEGT policy instrument employed for on-the-ground operationalization is not likely to result in the desired outcomes in terms of effectively influencing the interaction between state and non-state actors.

An important contextual factor affecting policy implementation is the openness of the policy process, i.e. the degree to which non-state actors influence decision-making and are able to exercise regulatory authority (Wu 2010). Building on the proposition that REDD+ and FLEGT/VPA exemplify international and transnational efforts to influence domestic practices, these policies can be further defined as increasingly relevant not only for the behavior of states, but also for the non-state actors active within those states, i.e. civil society and domestic firms. Cameroon's forest and environmental sectors have been described as lacking inclusiveness, i.e. not open to non-state actors (Dkamela et al. 2014; Korhonen-Kurki et al. 2014). REDD+ and FLEGT/VPA directly attempt to redress this situation. Our analysis in this chapter aims to convey the knowledge generated by the cumulative findings of the embedded case studies regarding interaction between state and non-state regulatory authority. This then allows for theorizing how such interactions can be better designed to ratchet up standards in the pursuit of the public goods of justice and sustainability.

The ability of REDD+ and FLEGT/VPA to influence on-the-ground behavior may be related to the potentially sensitive issues of sovereignty that may arise when travelling along the direct access pathway (Bernstein \& Cashore 2012). In the context of Cameroon, numerous scholars have attributed the lack of effective forest policy implementation to weak national commitment, considered symptomatic of post-colonial states (Dkamela et al. 2014, citing Kapoor 2002). Further, "internationally driven national forest policy processes tend to encounter massive implementation challenges" simply due to the fact that they stem from global priorities that may not reflect national policy agendas (Dkamela et al. 2014). Cameroon's overarching economic development objectives as outlined in its Vision 2035 focus on investments in agro-industry, infrastructure and manufacturing, with less emphasis on sustainable forest management (ROC 2009).

In Cameroon, scholars and practitioners present different findings related to the relevance of multi-stakeholder engagement in the REDD+ policy processes. Some criticize REDD+ for being based on externally driven policy reforms, paralleling the failure of the 1994 forest law reform process (Dkamela et al. 2014). These scholars argue that the lack of national ownership of the policy process fundamentally limited the inclusiveness of the 1994 forest law reform, stating "civil society and forestdwelling communities had little or no involvement in the debates on the law," which resulted in "the law's basis in technical information and foreign ideologies, and its omission of forest-dwelling communities' knowledge and opinions," making implementation of the law "highly likely to fail" (ibid., p. 6). The documented concentration of REDD+ technical knowledge, information, and resources in international actors explains why these authors believe REDD+ risks implementation failure similar to the 1994 forest law (ibid.). On the other hand, Cameroon's VPA negotiations have been highly praised for providing the first instance of government and civil society representatives sitting around the same table (Bollen \& Ozinga 2013; Wodschow et al. 2016). Since the negotiations closed, however, the 
ability of non-state actors to influence policy-making related to VPA implementation has been considerably weakened (Wodschow et al. 2016, p. 7).

An analysis of the barriers to VPA implementation reveals that decisions made about different types of policy levels- especially objectives, mechanism/calibrations and settings - can explain whether, when, and how, global interventions reinforce or alter domestic state-societal relations and problem solving on the ground. Overall, the technical policy choices made to advance the VPA in Cameroon do not seem well equipped to lead to significant and durable change on the ground. This is owed in large part to Cameroon's informal sector being ill-suited to the formalization approach of the VPA. Rather, it seems that significant reforms of the underlying structural dynamics - both in the forest administration as well as the legal framework governing how forest resources are distributed between international and domestic market-oriented enterprise - are needed before the VPA's proposed TLAS can benefit the domestic sector. Such reforms, in turn, require that those making decisions about policy objectives, settings and calibrations take into account, and more clearly incorporate, domestic historical practices and controversies. This also means making sure that choices over calibrations are consistent with broader policy goals and objectives, rather than working at cross purposes. For instance, the formal goal of the VPA process was to enhance socioeconomically equitable development. Yet this goal seems to be overshadowed by more narrow tasks, such as the delivery of FLEGT licenses for timber exports to the EU. While important as a short term step, this narrower focus on TLAS implementation to generate FLEGT licenses for EU timber exports risks missing or even undermining the broader governance and socioeconomic objectives of the FLEGT Action Plan.

To be sure, the case of Cameroon demonstrates how the translation of international forest policies through the direct access pathway has resulted in technological solutions as a procedural means for tackling the complex governance challenges inhibiting effective legality. Cameroon's forest sector - similar to those of many tropical forest countries suffering from so-called resource curses suffers from weak rule of law (Cerutti et al. 2013). Acknowledging the magnitude of the problem, it becomes clear that governance reform in Cameroon requires drawing on technical data-collection systems as a means rather than an end. Failure to do so raises the risk that the TLAS will exacerbate the informal collection of payments (Carodenuto \& Cerutti 2014). This is because timber legality in Cameroon is based on the sector's pre-existing paper-based system whereby companies require various official papers proving that they have paid different taxes, respected various norms, etc. These papers are generally obtained through bribes. Especially in the domestic market, the rules are very unclear, allowing various administrative agents from different government agencies to demand "papers" or "official stamps" on an ad-hoc basis (Cerutti et al. 2013). The risk with FLEGT/VPA is that now these papers, especially the FLEGT legality certificate itself, have even more value. Proving the underlying legality of any paper is extremely complex, however.

We also see several positive opportunities emerging from this analysis. A more nuanced look at instrument choice and design may provide a window of opportunity for policy learning efforts that focus on generating multi-stakeholder attention and knowledge about the causal processes through which global interventions might influence on-the-ground problems, and the strategic implications of these processes. This type of effort focuses greater attention on linking decisions about policy mechanisms, calibrations and settings to the causal pathways that might be unleashed by those decisions. This means, for example, that promoting the implementation process on the basis of its participatory nature means taking a closer look at the governance context, which may further entrench existing power relations rather than fostering equitable socioeconomic development. Refocusing the agenda on developing policy instruments that are operational and meet policy aims may help to move forward with effective policy implementation.

This research helps to better unpack the actual effects of policy instruments and to recognize when unintended consequences may undermine the basic purpose of the policy itself. With regard to FLEGT, the expected forest governance reforms relating to reduced corruption and improved law enforcement that are brought about by VPA implementation should benefit all timber operators, 
domestic and international. However, the policy means, or the TLAS, is designed so that there is a significant risk that Forestry Ministry officials will seek more or higher bribes for the papers required by the TLAS, with the most valuable paper being the FLEGT license itself. Further, given that the TLAS is based on formal law, it is highly likely that the informal domestic market will be excluded from the main benefits resulting from VPA implementation while power will be increasingly concentrated in the hands of concession-owning forestry industries. The TLAS demonstrates how technology can act as a channel through which to achieve policy goals, but also as a tool for further exploiting existing power imbalances (Cashore 2015). Taken together, two observations stand out. First, it is clear that policy makers must carefully identify, and understand, the causal processes through which choices about mechanisms, calibrations, and settings in TBG systems might influence domestic processes. Second, they must also expand their attention to a range of causal pathways, rather than focusing so much attention on market logics. Social norms, informal institutions and historical contexts all play important roles in influencing the how specific policy instruments become influential and effective. 


\section{References}

Assembe-Mvondo, S, Colfer, CJP, Brockhaus, M \& Tsanga, R 2014, 'Review of the legal ownership status of national lands in Cameroon: A more nuanced view' (en), Development Studies Research, vol. 1, no. 1, pp. 148-60.

Bartley, T 2014, 'Transnational governance and the re-centered state: Sustainability or legality?' (en), Regulation \& Governance, vol. 8, no. 1, pp. 93-109.

Bernstein, S \& Cashore, B 2012, 'Complex global governance and domestic policies: Four pathways of influence' (en), International Affairs, vol. 88, no. 3, pp. 585-604.

Bollen, A \& Ozinga, S 2013, Improving Forest Governance: A comparison of FLEGT VPAs and their impact (en), FERN, Brussels, Belgium.

Bourges, Carodenuto, S, Nguemadji M., Njomaha, C \& Tolo, M 2014, Mission d'appui à I'identification de projets pilotes REDD+ au Cameroun: Etude préparatoire pour la mise en œuvre du R-PP (fr), Rapport pour la GIZ au Cameroun.

Buttoud, G 1999, 'Principles of participatory processes in public decision making' (en), in Hunter, I., Korhonen, M., Pajari, B. (ed.), Regional Forest Programmes: A Participatory Approach to Support Forest Based Regional Development (da), Joensuu, Finland, pp. 11-28.

--(ed.) 2011, Special issue: Change in forest governance as a collective learning process (eng), Forest policy and economics, vol. 13.2011,2, Elsevier, Amsterdam.

Carodenuto, S 2016, Access to information and non-state regulatory authority-a case study of REDD+ and FLEGT/VPA access to information in Cameroon (en), unpublished, Working paper manuscript, available upon request.

Carodenuto, S \& Cerutti, PO 2014, 'Forest Law Enforcement, Governance and Trade (FLEGT) in Cameroon: Perceived private sector benefits from VPA implementation' (en), Forest Policy and Economics, vol. 48, pp. 55-62.

Carodenuto, S \& Kalame, F 2015, 'Operationalizing Free, Prior and Informed Consent (FPIC) for REDD+: Insights from the National FPIC Guidelines of Cameroon: Special Issue: The Legal Aspects of REDD+ Implementation: Translating the International Rules into Effective National Frameworks' (en), Carbon \& Climate Law Review, vol. 9, no. 2, pp. 156-67, $<$ http://cclr.lexxion.eu/article/CCLR/2015/2/8>.

Carodenuto, S, Merger, E, Essomba, E, Panev, M, Pistorius, T \& Amougou, J 2015, 'A Methodological Framework for Assessing Agents, Proximate Drivers and Underlying Causes of Deforestation: Field Test Results from Southern Cameroon' (en), Forests, vol. 6, no. 1, pp. 203-24.

Carodenuto, SL \& Ramcilovic-Suominen, S 2014, 'Barriers to VPA implementation: a case study of Cameroon's private forestry sector' (en), International Forestry Review, vol. 16, no. 3, pp. 27888.

Cashore, B. and S. Lupberger (2016). Protocol for Policy Learning Through Pathways of Influence. Yale University GEM Initiative.

Cashore, B., et al. (2016). Can Legality Verification enhance local rights to forest resources? Piloting the policy learning protocol in the Peruvian forest context, Yale University GEM Initiative in collaboration with IUFRO

Cashore, B, Elliot, C, Pohnan, E, Stone, M \& Jodoin, S 2016, 'Achieving sustainability through market mechanisms' (en), in R Panwar, RA Kozak \& E Hansen (eds), Forests, business and sustainability (en), The Earthscan forest library, Routledge, London, pp. 45-70.

Cashore, B, Galloway, G, Cubbage, F, Humphreys, D, Katila, P, Levin, K, Maryudi, A, McDermott, C \& McGinley, K 2010, Ability of institutions to address new challenges (en), Vienna. 
Cashore, B, Göhler, D, Hoogeveen, H, Rayner, J \& Verkooijen, P 2011, Learning about policy learning: designing a global forest governance learning architecture (en), St. Gallen.

Cashore, B \& Howlett, M 2007, 'Punctuating Which Equilibrium?: Understanding Thermostatic Policy Dynamics in Pacific Northwest Forestry' (en), American Journal of Political Science, vol. 51, no. 3, pp. 532-51.

Cashore, B \& Stone, MW 2014, 'Does California need Delaware?: Explaining Indonesian, Chinese, and United States support for legality compliance of internationally traded products' (en), Regulation \& Governance, vol. 8, no. 1, pp. 49-73.

Cerutti, P \& Fomété, T 2009, 'The forest verification system in Cameroon', Chapter 11 (en), in D Brown, K Schreckenberg, N Bird, P Cerutti, F Del Gatto \& C Diaw (eds), Legal timber: Verification and governance in the forest sector (en), Overseas Development Institute, London, pp. 135-47.

Cerutti, PO \& Lescuyer, G 2011, The domestic market for small-scale chainsaw milling in Cameroon: Present situation, opportunities and challenges (eng), Occasional paper / CIFOR, vol. 61, CIFOR; Niedersächsische Staats- und Universitätsbibliothek, Bogor, <http://webdoc.sub.gwdg.de/ebook/serien/yo/CIFOR_OP/61.pdf>.

Cerutti, PO, Tacconi, L, Lescuyer, G \& Nasi, R 2013, 'Cameroon's Hidden Harvest: Commercial Chainsaw Logging, Corruption, and Livelihoods' (en), Society \& Natural Resources, vol. 26, no. 5 , pp. 539-53.

Dkamela, GP, Brockhaus, M, Kengoum Djiegni, F, Schure, J \& Assembe Mvondo, S 2014, 'Lessons for REDD+ from Cameroon's past forestry law reform: a political economy analysis' (en), Ecology and Society, vol. 19, no. 3, viewed 28 August 2014.

Eberlein, B, Abbott, KW, Black, J, Meidinger, E \& Wood, S 2014, 'Transnational business governance interactions: Conceptualization and framework for analysis' (en), Regulation \& Governance, vol. 8, no. 1, pp. 1-21.

EC 2003, 'Communication from the Commission to the Council and the European Parliament: Forest Law Enforcement, Governance and Trade (FLEGT), Proposal for an EU Action Plan' (en), COM (2003) 251 final, Commission of the European Communities, 2003.

Fripp, E, Carodenuto, S \& Culliane, L 2013, Voluntary Partnership Agreements (VPAs) - an opportunity to address corruption in the forest sector. (en), GIZ Forest Governance Programme Working Document.

Gupta, A \& Mason, M 2016, 'Disclosing or obscuring?: The politics of transparency in global climate governance' (en), Current Opinion in Environmental Sustainability, vol. 18, pp. 82-90.

Hall, PA 1993, 'Policy Paradigms, Social Learning, and the State: The Case of Economic Policymaking in Britain' (en), Comparative Politics, vol. 25, no. 3, p. 275.

Hansen, CP, van Brussels, J, Tuomasjukka, T \& Shannon, M 2013, Governance Research Agenda for FLEGT: Towards global forest governance research and action (ca), European Forest Institute.

Howlett, M 2000, 'Managing the "hollow state": Procedural policy instruments and modern governance' (en), Canadian Public Administration/Administration publique du Canada, vol. 43, no. 4, pp. 412-31.

Humphreys, D., et al. (Forthcoming). "Towards durable multistakeholder-generated solutions: The pilot application of a problem-oriented policy learning protocol to legality verification and community rights in Peru" "International Forestry Review.

Kapoor, I 2002, 'Capitalism, culture, agency: Dependency versus postcolonial theory' (fr), Third World Quarterly, vol. 23, no. 4, pp. 647-64.

Korhonen-Kurki, K, Sehring, J, Brockhaus, M \& Di Gregorio, M 2014, 'Enabling factors for establishing REDD+ in a context of weak governance' (en), Climate Policy, vol. 14, no. 2, pp. 167-86. 
Lescyuer et al. Valuing the Cameroonian forest Editorial. International Forestry Review. Volume 18, Supplement 1. October 2016, pp.1-3(3).

McDermott, C. L., Coad, L., Helfgott, A., \& Schroeder, H. (2012). Operationalizing social safeguards in REDD+: actors, interests and ideas. Environmental Science \& Policy, 21, 63-72.

McDermott, CL \& Ituarte-Lima, C 2016, 'Safeguarding what and for whom?: The role of institutional fit in shaping REDD+ in Mexico' (en), Ecology and Society, vol. 21, no. 1.

Melish, T \& Meidinger, E 2012, 'Protect, Respect, Remedy and Participate: 'New Governance' Lessons for the Ruggie Framework', Chapter 12 (en), in R Mareș (ed.), The UN guiding principles on business and human rights: Foundations and implementation (eng), The Raoul Wallenberg Institute human rights library, v. 39, Extenza Turpin distributor, Leiden, Boston, Biggleswade, England, pp. 303-36.

Mvondo, SA 2009, 'State Failure and Governance in Vulnerable States: An Assessment of Forest Law Compliance and Enforcement in Cameroon' (en), Africa Today, vol. 55, no. 3, pp. 85-102.

Panwar, R, Kozak, RA \& Hansen, E (eds) 2016, Forests, business and sustainability (en), The Earthscan forest library, Routledge, London.

Rayner, J, Buck, A \& Katila, P (eds) 2010, Embracing complexity: Meeting the challenges of international forest governance; a global assessment report (Englisch), IUFRO world series, vol. 28, International Union of Forest Research Organizations (IUFRO), Vienna, <http://www.iufro.org/download/file/6997/153/ws28_pdf/>.

ROC 2009, Cameroon Vision 2035, Ministry of Economy, Planning and Regional Development, Yaoundé, Cameroon.

- -2013, REDD+ Readiness Preparation Proposal (R-PP), Forest Carbon Partnership Facility, Yaoundé, Cameroon, <https://www.forestcarbonpartnership.org/sites/forestcarbonpartnership.org/files/Documents/ PDF/Feb2013/Cameroon\%20final\%20R-PP-English-January\%202013.pdf>.

ROC \& EU 2010, Partnership Agreement between the European Union and the Republic of Cameroon on Forest Law Enforcement, Governance and Trade in Timber and Derived Products to the European Union (FLEGT) (en), Republic of Cameroon and European Union.

Somorin, OA, Visseren-Hamakers, IJ, Arts, B, Sonwa, DJ \& Tiani, A 2014, 'REDD+ policy strategy in Cameroon: Actors, institutions and governance' (en), Environmental Science \& Policy, vol. 35, pp. 87-97.

Wasseige, Cd, Marcken, Pd \& Bayol, N 2012, The forests of the Congo basin: State of the forest 2010 (en), EUR / European Commission, vol. 25161, EUR-OP, Luxembourg.

Wodschow, A, Nathan, I \& Cerutti, P 2016, 'Participation, public policy-making, and legitimacy in the EU Voluntary Partnership Agreement process: The Cameroon case' (en), Forest Policy and Economics, vol. 63, pp. 1-10.

Wood, S, Abbott, KW, Black, J, Eberlein, B \& Meidinger, E 2015, 'The Interactive Dynamics of Transnational Business Governance: A Challenge for Transnational Legal Theory' (en), Osgoode Legal Studies Research Paper No. 40/2015, Transnational Legal Theory Special Issue, 2015, Forthcoming.

$\mathrm{Wu}, \mathrm{X} 2010$, The public policy primer: Managing the policy process (eng), Routledge textbooks in policy studies, Routledge, London, <http://www.loc.gov/catdir/enhancements/fy1105/2010006072-b.html>.

Yin, RK 2009, Case study research: Design and methods (eng), Applied social research methods series, 4th edn, vol. 5, Sage, Los Angeles. 